\title{
Reversible diabetes mellitus induced by use of, and improved after discontinuation of, the antiretroviral medication zidovudine:
} a case report

\author{
Kentaro Iwata ${ }^{1 *}$ and Wataru Ogawa ${ }^{2}$
}

\begin{abstract}
Background: With the advent of effective antiretroviral therapy, the care of patients with human immunodeficiency virus infection became more like that of other chronic diseases. Diabetes mellitus can also occur as one of the chronic illnesses affecting patients with human immunodeficiency virus infection. We report a case of newly developed diabetes mellitus in a patient with human immunodeficiency virus infection, most likely caused by the nucleoside analogue zidovudine, and its improvement after discontinuation of zidovudine.

Case presentation: A Chinese man in his 30s visited our outpatient clinic for routine follow-up of human immunodeficiency virus infection. Blood tests showed hyperglycemia with a glucose level of $31.8 \mathrm{mmol} / \mathrm{L}$ and hemoglobin A1c of $8.5 \%$. He was diagnosed with diabetes mellitus and treated with oral diabetic medications. The use of zidovudine was suspected as the cause of his diabetes, and it was replaced by other antiretroviral medication. His hyperglycemia improved, and he now no longer requires diabetic medications.

Conclusions: Diabetes mellitus can develop with the use of antiretroviral medications, but its occurrence associated with use of zidovudine is quite rare. Healthcare personnel should be aware of this rare, yet important, side effect.
\end{abstract}

Keywords: HIV infection, Diabetes mellitus, Zidovudine

\section{Background}

With the advent of effective antiretroviral therapy (ART; formerly known as highly active antiretroviral therapy, or HAART) in late 1990s, the prognosis of patients with human immunodeficiency virus (HIV) infection improved significantly. The patients live longer, and as a result they face more health problems associated with aging [1]. Although HIV infection per se is not known to be associated with increased incidence of diabetes mellitus, some antiretroviral agents, such as protease inhibitors, may increase the risk of developing diabetes [2]. We report a rare case of a patient with diabetes mellitus, most likely caused by zidovudine, a classical nucleoside reverse transcriptase inhibitor, which improved by discontinuing the medication.

\footnotetext{
* Correspondence: kentaroiwata1969@gmail.com

${ }^{1}$ Division of Infectious Diseases, Department of Microbiology and Infectious Diseases, Kobe University Graduate School of Medicine, 7-5-2 Kusunokicho, Chuo-ku, Kobe, Hyogo 650-0017, Japan

Full list of author information is available at the end of the article
}

\section{Case presentation}

A Chinese man in his 30s visited our outpatient clinic for routine follow-up of HIV infection. He had become infected with HIV about 10 years earlier and had been followed at our outpatient clinic since 7 years prior to the current presentation. He had never had hyperglycemia during follow-up. Upon arrival, he stated that he was in his usual state of health and denied any symptoms such as polydipsia or polyuria, except for weight loss, but he did not recall the precise amount of weight loss or its duration. He stated that he was an occasional binge drinker of alcohol but denied any alcohol intake since 1 month prior to the current presentation. His height was $162 \mathrm{~cm}$, and his weight was $42.8 \mathrm{~kg}$. His physical examination was unremarkable, and he did not have any bodily habitus to suggest lipodystrophy. His past medical history, besides HIV infection, included depression, multiple alcohol binge-drinking periods with 
repeated episodes of acute pancreatitis, hypertriglyceridemia, and two episodes of amoebic liver abscess. His medications included Combivir ${ }^{\circ}$ (zidovudine and lamivudine; ViiV Healthcare, Brentford, UK), raltegravir, and fenofibrate. He was seen by a psychiatrist and had received sertraline, levomepromazine, flunitrazepam, and quazepam, but he had discontinued all medications approximately 1 month prior to the current presentation after discussion with his psychiatrist. He denied tobacco use, illicit drug use, or use of any supplements. He had been taking Combivir (zidovudine and lamivudine) and KALETRA $^{\circ}$ (lopinavir/ritonavir; AbbVie, Chicago, IL, USA) for several years, but KALETRA ${ }^{\circ}$ was switched to atazanavir/ritonavir because of an interaction with psychiatric medications 6 years ago. They were again changed to raltegravir 4 years ago because of hypertriglyceridemia. With ART consisting of Combivir ${ }^{\circledR}$ and raltegravir, the patient's HIV infection had been stable, with a latest $\mathrm{CD} 4^{+}$ T lymphocyte count being $1065 / \mathrm{mm}^{3}$ and an undetectable viral load (Table 1).
Blood tests done on the day of the current presentation showed elevated glucose of $31.8 \mathrm{mmol} / \mathrm{L}$, sodium $130 \mathrm{mmol} / \mathrm{L}$, and potassium $4.3 \mathrm{mmol} / \mathrm{L}$, with mildly elevated liver transaminases. The patient's hemoglobin A1c was $8.5 \%$. His arterial blood gas analysis on room air showed a $\mathrm{pH}$ of 7.404, partial pressure of oxygen of $115 \mathrm{mmHg}$, partial pressure of carbon dioxide of 36.8 $\mathrm{mmHg}$, bicarbonate of $22.5 \mathrm{mmol} / \mathrm{L}$, and an anion gap of $11.5 \mathrm{mmol} / \mathrm{L}$ (Table 1 ).

Because of the patient's hyperglycemia without acidosis, we presumptively diagnosed that he had newly developed diabetes mellitus and considered the possibility of insulin depletion as a result of repeated acute pancreatitis. We then referred him to our endocrinology clinic. Additional blood tests were ordered, and it turned out that his blood C-peptide level was $2.69 \mathrm{ng} / \mathrm{ml}$ (normal range $0.69-2.45 \mathrm{ng} / \mathrm{ml}$ ), his blood insulin level was $15 \mu \mathrm{U} / \mathrm{ml}$ (normal range $5-30 \mu \mathrm{U} / \mathrm{ml}$ ), and his glutamic acid decarboxylase antibody level was $0.6 \mathrm{U} / \mathrm{ml}$ (normal range $0-1.49 \mathrm{U} / \mathrm{ml}$ ). Unlike our initial assessment, we

Table 1 Laboratory results of the patient

\begin{tabular}{|c|c|c|c|}
\hline Variables & Reference ranges, adults & On day of visit & $\begin{array}{l}\text { Blood test results } 2 \text { months after } \\
\text { discontinuing diabetes medications }\end{array}$ \\
\hline White cell count, per $\mathrm{mm}^{3}$ & $4000-8500$ & 13,100 & 6400 \\
\hline Hemoglobin, g/dl & $13.6-17$ & 12.9 & 14.6 \\
\hline Platelet, per $\mathrm{mm}^{3}$ & $130,000-300,000$ & 381,000 & 341,000 \\
\hline Sodium, mmol/L & $137-146$ & 130 & 136 \\
\hline Potassium, mmol/L & $3.5-4.7$ & 4.3 & 3.5 \\
\hline Chloride, mmol/L & 99-109 & 96 & 110 \\
\hline Calcium, mg/dl & $8.8-10.1$ & 10.1 & Not measured \\
\hline Phosphorus, mg/dl & $2.4-4.5$ & 4.4 & Not measured \\
\hline Albumin, $\mathrm{g} / \mathrm{dl}$ & $4.1-5$ & 4.6 & 4.9 \\
\hline Aspartate aminotransferase, U/L & $13-31$ & 36 & 25 \\
\hline Alanine aminotransferase, $\mathrm{U} / \mathrm{L}$ & $8-34$ & 106 & 37 \\
\hline Total bilirubin, mg/dl & $0.3-1$ & 0.5 & 0.5 \\
\hline Blood urea nitrogen, mg/dl & $9-22$ & 14.5 & 12.1 \\
\hline Creatinine, mg/dl & $0.5-1.3$ & 0.69 & 0.79 \\
\hline Glucose, nonfasting, mmol/L & $4.0-6.0$ & 31.8 & 7.5 \\
\hline Hemoglobin A1c, \% & & 8.5 & 6.0 \\
\hline \multicolumn{4}{|l|}{ Blood gas, arterial, room air } \\
\hline $\mathrm{pH}$ & $7.38-7.46$ & 7.404 & \\
\hline Partial pressure of oxygen, $\mathrm{mmHg}$ & 74-108 & 115.0 & \\
\hline Partial pressure of carbon dioxide, $\mathrm{mmHg}$ & $32-46$ & 36.8 & \\
\hline Bicarbonate, $\mathrm{mmol} / \mathrm{L}$ & $21-29$ & 22.5 & \\
\hline Anion gap, $\mathrm{mmol} / \mathrm{L}$ & $10-20$ & 11.5 & \\
\hline $\mathrm{CD}^{+}{ }^{+}$T-lymphocyte count, per $\mathrm{mm}^{3}$ & & 1065 & 865 \\
\hline HIV RNA, copies/ml & & Undetectable & Undetectable \\
\hline
\end{tabular}

AST Aspartate aminotransferase, ALT Alanine aminotransferase, BUN Blood Urea Nitrogen, PaO2 Partial pressure of oxygen, PaCO2 Partial pressure of carbon dioxide, $\mathrm{HCO} 3$ Bicarbonate, HIV human immunodeficiency virus, RNA ribonucleic acid 
then judged him to have diabetes mellitus with preserved insulin secretion from the pancreas, and he was prescribed glimepiride $1 \mathrm{mg}$ once daily. Sitagliptin 50 mg once daily and metformin $250 \mathrm{mg}$ twice daily were added later, and his hyperglycemia normalized with a decreasing hemoglobin A1c level. A computed tomographic scan of the patient's abdomen with contrast did not show any evidence of chronic pancreatitis, but it showed sporadic low-density areas in the liver, suggesting partial fatty liver.

By this time, we began to suspect the antiretroviral medications, particularly zidovudine, as the cause of the patient's diabetes. Combivir ${ }^{\circ}$ was switched to TRUVADA $^{\circ}$ (tenofovir disoproxil and emtricitabine; Gilead Sciences, Foster City, CA, USA) 4 months after the detection of diabetes mellitus. His hyperglycemia further improved, and his medications for diabetes were decreased. Seven months after the patient's initial presentation, all diabetes medications were stopped. $\mathrm{He}$ remained stable after discontinuing all diabetic medications, with a fasting glucose level of $7.5 \mathrm{mmol} / \mathrm{L}$ and a hemoglobin A1C of $6.0 \%$ (9 months after the initial visit) (Table 1 ).

\section{Discussion}

The patient developed diabetes mellitus with relatively preserved insulin secretion while on ART, and the discontinuation of zidovudine improved his hyperglycemia to a level where he did not require diabetes medications. Because lamivudine and emtricitabine are structurally very similar [3], switching from lamivudine to emtricitabine is unlikely to have contributed to improving his hyperglycemia. He had been receiving protease inhibitors (lopinavir/ritonavir, then atazanavir with ritonavir, both of which are known to cause diabetes in patients with HIV infection [4-7]), but they were discontinued years before the current presentation and are unlikely to have been the cause of his diabetes.

Old antiretroviral medications such as zalcitabine, didanosine, stavudine, and medications for treating opportunistic infections, such as pentamidine, can cause pancreatitis and may lead to the development of diabetes [8-11]. Although rare, cohort studies showed that the use of zidovudine was associated with increased risk of developing diabetes [12-14], and it was an independent risk factor after adjusting for lipodystrophy [12].

The pathogenesis of diabetes caused by zidovudine remains unknown, but it may be associated with lipodystrophy or mitochondrial toxicity [12, 15]. Although our patient did not have the typical bodily habitus of lipodystrophy, some could suspect that his weight loss could have been a reflection of lipoatrophy caused by zidovudine, which could have contributed to the development of diabetes. However, the patient's weight and appearance remained unchanged 5 months after stopping zidovudine. Replacement of the causative thymidine analogue usually leads to improvement of lipoatrophy [16]. He had partial fatty liver, which is a common finding of HIV-related lipoatrophy, but his history of binge alcohol intake also might have been the cause [17]. Therefore, it is more plausible to consider that his diabetes was caused by the direct effect of zidovudine, not secondary to lipodystrophy syndrome.

The management of diabetes in patients with HIV infection is basically the same as that for patients without HIV infection, but the discontinuation of ART medications likely to have caused diabetes is recommended [18]. Even though population-based studies suggested an association between the use of zidovudine and diabetes, we were not able to find any case report or series demonstrating the development of diabetes after the use of zidovudine (and improvement after its discontinuation).

One might consider that the discontinuation of medications for depression might have affected the pharmacokinetics or pharmacodynamics of zidovudine. We were not able to find any interaction between zidovudine and these medications, but this possibility has to be kept in mind because some drug interactions could remain unknown [19].

\section{Conclusions}

We encountered a case of new-onset diabetes in a patient with HIV infection in whom the discontinuation of zidovudine improved glycemic control. The rare occurrence of diabetes due to the use of zidovudine would not necessarily preclude the use of this medication, but one should be aware of this side effect, particularly in patients who already have or have developed diabetes while receiving zidovudine.

\section{Acknowledgements}

We thank Dr. Daniel J. Mosby for correction of English grammar and usage.

Funding

None.

Availability of data and materials

Data sharing is not applicable to this article, because no datasets were generated or analyzed during the present study.

\section{Authors' contributions}

$\mathrm{Kl}$ drafted the manuscript, and WO reviewed and revised it. Both authors reviewed the final manuscript to reach agreement. Both authors read and approved the final manuscript

\section{Competing interests}

The authors declare that they have no competing interests.

\section{Consent for publication}

Written informed consent was obtained from the patient for publication of this case report and any accompanying images. A copy of the written consent is available for review by the Editor-in-Chief of this journal. 


\section{Ethics approval and consent to participate}

Not applicable.

\section{Publisher's Note}

Springer Nature remains neutral with regard to jurisdictional claims in published maps and institutional affiliations.

\section{Author details}

'Division of Infectious Diseases, Department of Microbiology and Infectious Diseases, Kobe University Graduate School of Medicine, 7-5-2 Kusunokicho, Chuo-ku, Kobe, Hyogo 650-0017, Japan. ${ }^{2}$ Division of Diabetes and Endocrinology, Department of Internal Medicine, Kobe University Graduate School of Medicine, Kobe, Japan.

Received: 10 January 2017 Accepted: 21 May 2017

Published online: 14 June 2017

\section{References}

1. Cahill S, Valadéz R. Growing older with HIV/AIDS: new public health challenges. Am J Public Health. 2013;103:e7-15.

2. Tripathi A, Liese AD, Jerrell JM, Zhang J, Rizvi AA, Albrecht $H$, et al. Incidence of diabetes mellitus in a population-based cohort of HIV-infected and nonHIV-infected persons: the impact of clinical and therapeutic factors over time. Diabet Med. 2014:31:1185-93.

3. Frampton JE, Perry CM. Emtricitabine. Drugs. 2005;65:1427-48.

4. Dubé MP, Johnson DL, Currier JS, Leedom JM. Protease inhibitor-associated hyperglycaemia. Lancet. 1997;350:713-4.

5. Visnegarwala F, Krause KL, Musher DM. Severe diabetes associated with protease inhibitor therapy. Ann Intern Med. 1997;127:947.

6. Lee ECC, Walmsley S, Fantus IG. New-onset diabetes mellitus associated with protease inhibitor therapy in an HIV-positive patient case report and review. CMAJ. 1999;161:161-4.

7. Palma-Aguirre A, Halabe-Cherem J, Nellen-Hummel H, Aburto-Mejía E, IbarraHerrera E, Ponce-Monter $\mathrm{H}$. Protease inhibitor-associated hyperglycemia in Mexican patients with HIV infection. Arch Med Res. 2000;31:81-4.

8. Ledergerber B, Furrer H, Rickenbach M, Lehmann R, Elzi L, Hirschel B, et al. Factors associated with the incidence of type 2 diabetes mellitus in HIV-infected participants in the Swiss HIV Cohort Study. Clin Infect Dis. 2007:45:111-9.

9. Grinspoon SK, Bilezikian JP. HIV disease and the endocrine system. N Engl J Med. 1992;327:1360-5.

10. HIVInfo.us. Hivid - zalcitabine - ddC. http://www.hivinfo.us/zalcitabine.html. Accessed 6 Jan 2017.

11. Capeau J, Bouteloup V, Katlama C, Bastard JP, Guiyedi V, Salmon-Ceron D, et al. Ten-year diabetes incidence in 1046 HIV-infected patients started on a combination antiretroviral treatment. AIDS. 2012;26:303-14.

12. De Wit S, Sabin CA, Weber R, Worm SW, Reiss P, Cazanave C, et al. Incidence and risk factors for new-onset diabetes in HIV-infected patients: the data collection on adverse events of anti-HIV drugs (D:A:D) study. Diabetes Care. 2008;31:1224-9.

13. Lo YC, Chen MY, Sheng WH, Hsieh SM, Sun HY, Liu WC, et al. Risk factors for incident diabetes mellitus among HIV-infected patients receiving combination antiretroviral therapy in Taiwan: a case-control study. HIV Med. 2009:10:302-9.

14. Riyaten P, Salvadori N, Traisathit P, Ngo-Giang-Huong N, Cressey TR, Leenasirimakul $\mathrm{P}$, et al. New-onset diabetes and antiretroviral treatments in HIV-infected adults in Thailand. J Acquir Immune Defic Syndr. 2015;69:453-9.

15. Blümer RM, van Vonderen MG, Sutinen J, Hassink E, Ackermans M, van Agtmael MA, et al. Zidovudine/lamivudine contributes to insulin resistance within 3 months of starting combination antiretroviral therapy. AIDS. 2008; 22:227-36

16. Carr A, Workman C, Smith DE, Hoy J, Hudson J, Doong N, et al. Abacavir substitution for nucleoside analogs in patients with HIV lipoatrophy: a randomized trial. JAMA. 2002;288:207-15.

17. Guaraldi G, Squillace N, Stentarelli C, Orlando G, D'Amico R, Ligabue G, et al. Nonalcoholic fatty liver disease in HIV-infected patients referred to a metabolic clinic: prevalence, characteristics, and predictors. Clin Infect Dis. 2008:47:250-7

18. Monroe AK, Glesby MJ, Brown TT. Diagnosing and managing diabetes in HIV-infected patients: current concepts. Clin Infect Dis. 2015;60:453-62.

19. Block LH. Polymedicine: known and unknown drug interactions. J Am Geriatr Soc. 1982;30(11 Suppl):S94-8.

\section{Submit your next manuscript to BioMed Central and we will help you at every step:}

- We accept pre-submission inquiries

- Our selector tool helps you to find the most relevant journal

- We provide round the clock customer support

- Convenient online submission

- Thorough peer review

- Inclusion in PubMed and all major indexing services

- Maximum visibility for your research

Submit your manuscript at www.biomedcentral.com/submit 